\title{
Seeing the Corruption from Digital Media Perspective: Case of Corruption in the Indonesia Ministry of Religion
}

\author{
Suswanta $^{1}$, Arissy Jorgi Sutan ${ }^{2}$, Misran $^{3}$, Achmad Nurmandi $^{4}$, M Syamsurrijal $^{5}$, Hasse Jubba ${ }^{6}$ \\ \{suswanta@umy.ac.id ${ }^{1}$, arissy.jorgi.psc20@mail.umy.ac.id², misranalfarabi@gmail.com ${ }^{3}$, \\ nurmandi_achmad@umy.ac.id ${ }^{4}$, hasse@umy.ac.id $\left.{ }^{6}\right\}$ \\ Department Government Affairs Administration, Jusuf Kalla School of Government, \\ Universitas Muhammadiyah Yogyakarta ${ }^{1,2,3,4}$, Defartement of Islamic Politics, Universitas \\ Muhammadiyah Yogyakarta 5,6
}

\begin{abstract}
This research aims to know the digital media theme, narration, and relation about the corruption of the Indonesia Ministry of Religion. Corruption is an active crime in order to make wealth by power. This research using the qualitative method with the analysis of the digital data using Q-DAS (Qualitative Data Analysis Software) Nvivo 12Plus., with descriptive way deliver the value and result. This research found that: First, theme in digital media dominant in there; Korupsi, Soap, and Terdakwa. Second, Thera appears the relation of the theme and tends to be strong. Third, the narration appears to be spared dominant with the institution name KPK; the word also appears to show the defendant of a corruption case.
\end{abstract}

Keywords: Ministry of Religion; Corruption; Social media; Indonesia

\section{Introduction}

This research tries to know the media perspective of corruption in the Indonesian Ministry of Religion and some of the Islamic party members. In this case, the research focused on the media content to frame the corruption case in the ministry of Religion. This research focused on three media there are Detik, Tempo, and Kompas. Corruption is an active crime in order to make wealth by power. There are some type of the Corruption according Stückelberger (Orok, Justus, and Okafor 2020; Widiyanto 2017):

1. The corruption of poverty, Its origins can be traced back to impoverishment. That is the 'daily misuse of delegated authority among low- and mid-level elected officials during its dealings with regular people, many of whom try to access essential goods and services in locations such as clinics, universities, law enforcement, and other organizations.

2. The corruption of power, from the other side, the corruption of power is driven by the desire for increased control, authority, or prosperity, or by the wanting to defend oneself current power and political status.

3. The corruption of procurement, paying bribes to sell products and services when customers, however, will be unable to purchase goods and services. 
4. The corruption of acceleration provides the intention of delivering products or services more quickly or on a schedule that would not be available or delivered on time or would only have been accessible at quite a higher administrative burden.

5. The corruption of donations misappropriates contributions for reasons apart from those specified, either within the receiving organization or for private gain.

6. The corruption of sexual abuse is the misuse of such a place of authority for the nonmonetary benefit and in the form of sexual contact and abuse, typically of women, by men in positions of qualified dominance, such as educators and pastors, and medical doctors, among others.

7. Grey corruption, among conspiracy, corruption, nepotism, favoritism, or clientelistic.

On the other side, Religion in this case To begin, once the premise that since a 'bureaucracy' or secular governance can promote stability and overall growth loses its appeal, Religion offers different forms of social and political organization. Second, a large bulk of Nigeria's population is religious, and almost all sects adhere to a collection of universal principles that despise corruption and other actions deemed morally repugnant (Riaz et al., 2016; Yagboyaju 2017).

Since religious density is significantly correlated with anti-corruption activity, faith, as an informal structural factor and a component of social culture, does not affect stopping officials from engaging in unethical behavior and cannot minimize the risk of them engaging in corruptive activities (Gokcekus and Ekici 2020; Ngwoke 2020; Yahya et al. 2006; Zakaria 2018; Zarkadakis 2020). Additionally, the legal structures and the rule of law, as embodied in a structured institution structure and external oversight systems, continue to be critical in preventing corruption in a religious country like Indonesia. As a result, religiosity cannot be used as a substitute tool for preventing corruption(Jackson and Xing 2018; Makmur 2020; Ngwoke 2020).

This research using digital news data that from three media: Kompas, Detik, and Tempo, that related to the corruption case of the minister of Religion. This research tries to know what kind the media connect and narration about the corruption case in the Indonesia ministry of Religion (Font and Maguire-Jack 2020; Li, Wu, and Liang 2019; Makmur 2020; Nakagawa 2018; Orok et al. 2020; Riaz et al. 2016; Saar-Heiman, Lavie-Ajayi, and KrumerNevo 2017). This research uses three analyses: Chart analysis to know the theme of content on the news media. Cluster analysis to know what kind the relation of the topic. Word cloud analysis to know what kind the narrative that separated on the digital media about corruption.

This research seeks to answer three questions there are:

1. What kind of digital media content theme about the corruption in the Indonesia Ministry of Religion.

2. What kind the topic or theme relation in case of corruption in the Indonesia ministry of Religion in digital media.

3. What kind the popular narrative spread using digital media about corruption in Indonesia Ministry of Religion.

\section{Methods}

This part tries to deliver the instrument and step of the analysis of the research. This research used digital media data from three media: Kompas, Detik, and Tempo, relevant to the theme of corruption in the Indonesia Minister of Religion. This research uses the Qualitative method to know the theme, relation, and narrative that spread in digital media about the 
corruption case in Indonesia minister of Religion. This research analyzes the digital data using Qualitative Data Analysis Software (Q-DAS), using Nvivo 12Plus (Kholid et al. 2015; Rahmat and Purnomo 2020; Setiawan and Nurmandi 2020). Using Nvivo 12Plus, in this case, is important to deliver the value and describe and classify the digital data purpose, using three analyses: Chart analysis to know what kind of the theme of content is on the news media. Cluster analysis to know what kind the relation of the topic. Word cloud analysis to know what kind the narrative that separated on the digital media about corruption. To deliver the value, also using Description way to deliver the meaning of the result and value.

\section{Result and Disscusion}

These parts are defined in three parts: first, the Digital media content theme about the corruption in Indonesia Ministry of Religion. Second, topic or theme relation in case of corruption in Indonesia ministry of Religion in digital media. Third, popular narratives spread using digital media about corruption in Indonesia's Ministry of Religion (Dormekpor 2015; Jajkowicz and Drobiszová 2015; Miklian and Birkvad 2016; Mukhammadsidiqov 2020; University of Stellenbosch. Department of Biblical Studies. and Swart 2015; Yagboyaju 2017).

\subsection{Digital Media Content in Case of Corruption in Indonesia Ministry of Religion}

This part tries to know what kind of digital media content theme in three media about corruption in Indonesia Ministry of Religion - in this case, using chart analysis to define and classification the theme and count them in the percent. The explanation is in figure 1 and table 1.

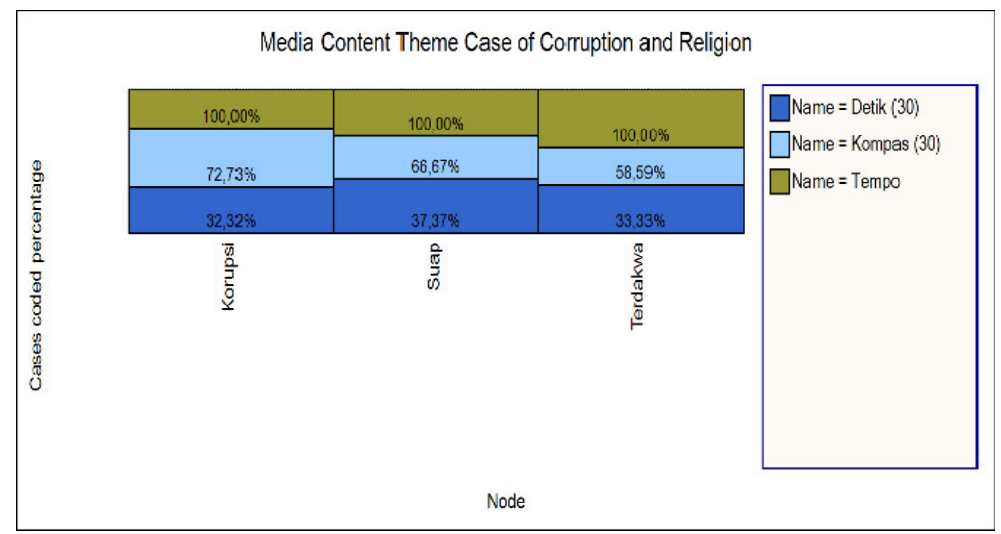

Fig 1. Digital media Content

Table 1. Digital media Content

\begin{tabular}{ccccc}
\hline Theme & Detik & Kompas & Tempo & Total \\
\hline Korupsi & $32,43 \%$ & $40,54 \%$ & $27,03 \%$ & $100 \%$ \\
Suap & $37,5 \%$ & $29,17 \%$ & $33,33 \%$ & $100 \%$ \\
Terdakwa & $33,33 \%$ & $25 \%$ & $41,67 \%$ & $100 \%$ \\
Total & $35,71 \%$ & $32,86 \%$ & $31,43 \%$ & $100 \%$ \\
\hline
\end{tabular}


The analysis shows that the theme is defined in three themes: korupsi, suap, and terdakwa. The theme of korupsi the highest is Kompas with 40,54\%, the second pole is detik with $32,43 \%$, and tempo with $27,03 \%$. The theme of Soap the highest is detik with $37,5 \%$, tempo with $33,33 \%$, and Kompas $29,17 \%$. The theme of terdakwa the highest is tempo with $41,67 \%$, detik with 33,33\% and Kompas 25\%. from the total the highest is detik with 35,71\%, second is Kompas with $32,86 \%$, and third place is tempo with $31,43 \%$. From that, we can see that digital media is dominant to show the corruption phenomenon by using three themes dominant korupsi, suap, and tredakwa. In this case, digital media classified the theme from the corruption phenomenon.

\subsection{Topic or Theme Relation in Case of Corruption in Indonesia Ministry of Religion in Digital Media}

In this case, it tries to know the topic or theme relation in corruption in Indonesia's Ministry of Religion in digital media. In this case, the relation appears with lower limit 0,5 and upper limit one from scale $-1,0$, and -1 . in this case, the explanation is in figure 2 and table 2 .

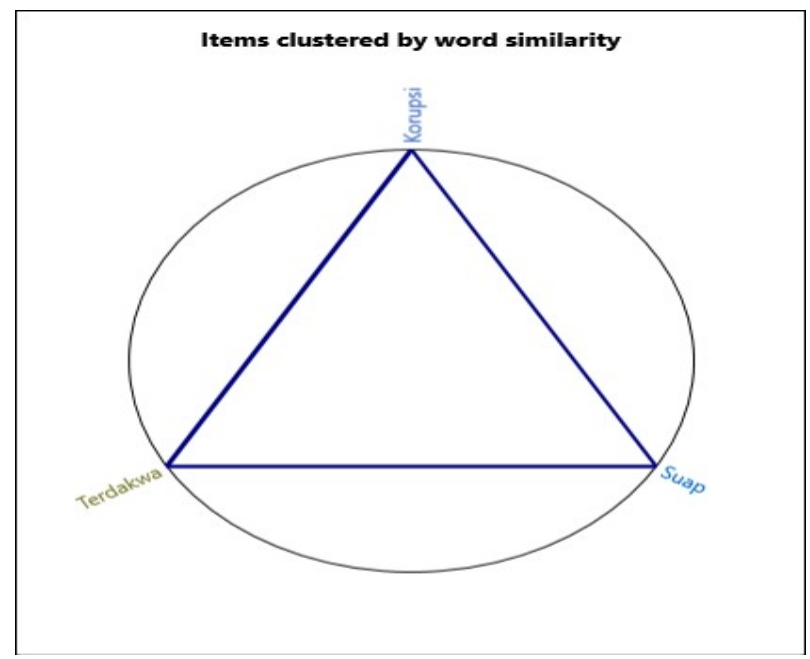

Fig 2. Digital media Relation Theme

Table 2. Digital media Relation Theme

\begin{tabular}{ccc}
\hline Code A & Code B & Pearson correlation coefficient \\
\hline Nodes $\backslash \backslash$ Media Nodes $\backslash \backslash$ Terdakwa & Nodes $\backslash \backslash$ Media Nodes $\backslash \backslash$ Korupsi & 0,909479 \\
Nodes $\backslash \backslash$ Media Nodes $\backslash \backslash$ Terdakwa & Nodes $\backslash \backslash$ Media Nodes $\backslash \backslash$ Suap & 0,772058 \\
Nodes $\backslash \backslash$ Media Nodes $\backslash \backslash$ Suap & Nodes $\backslash \backslash$ Media Nodes $\backslash \backslash$ Korupsi & 0,55994 \\
\hline
\end{tabular}

From that, we can see that the highest relation is Terdakwa with korupsi with a 0,909479 point. The second is the relation of terdakwa with suap with 0,772058 points. Third is realtion of suap and korupsi with 0,55994 point. In this analysis, we can see that the relationship appears and tends to be strong caused it can see in lower limit 0,5 scale. Its shows that the theme is related to another theme. 
3.3 Narration Spread in Digital Media in Case of Corruption in Indonesia Ministry of Religion in Digital Media

These analysis parts try to know what kind of narrative is spread in digital media - using 100 popular words. These parts using word cloud analysis. The analysis parts are in figure 3 and table 3 .

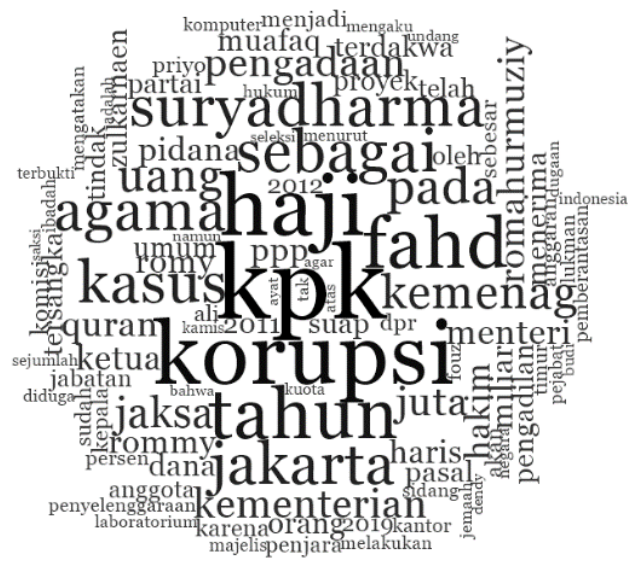

Fig 3. Narration on Digital media

Fig. 3. Top 10 Narration on Digital media

\begin{tabular}{cc}
\hline Word & Count \\
\hline Kpk & 754 \\
Korupsi & 644 \\
Haji & 626 \\
Fahd & 524 \\
Tahun & 524 \\
Sebagai & 436 \\
suryadharma & 430 \\
Kasus & 428 \\
Jakarta & 424 \\
Agama & 422 \\
\hline
\end{tabular}

From the analysis, we can see that digital media narration spread with the dominance is KPK with 754 counts, later word of korupsi with 644 counts, and the third is haji with 626 counts. From these parts, we can see that the narrative spread in this digital media dominance with the institution nema with KPK, but on the other side, the word appears to show the corruption aspect like korupsi, kasus, haji prefer to the hajj corruption in Ministry of Religion. Besides that, we can see names of the defendant of case corruption like fhad and suryadharma.

\section{Conclusion}

In this research we can found that theme content in the corruption case in the Indonesia Ministry of Religion is defined in three themes: korupsi, suap, and terdakwa. Digital media dominant to show the corruption phenomenon by using three themes dominant korupsi, suap, 
and tredakwa. In this case, digital media classified the theme from the corruption phenomenon. The relation of the theme appears, and it tends to be strong; it can see in lower limit 0,5 scale. Its shows that the theme is related to another theme. The institution name, like the KPK, dominates the narrative spread. Besides, the word appears to show the corruption aspect like korupsi, kasus, and haji prefer to the hajj corruption in Ministry of Religion. Besides that, we can see names of the defendant of case corruption like fhad and suryadharma. Beside that there are some limitation in this research like this research only focused on the digital data from the media in Indonesia.

\section{Acknowledgments}

Any acknowledgments authors wish to make should be included in a separate headed section at the end of the manuscript but before the list of references.

\section{References}

[1] Dormekpor, Evelyn. 2015. "Poverty and Gender Inequality in Developing Countries." Developing Country Studies 5(10):76-103.

[2] Font, Sarah A., and Kathryn Maguire-Jack. 2020. 'It's Not 'Just Poverty': Educational, Social, and Economic Functioning among Young Adults Exposed to Childhood Neglect, Abuse, and Poverty." Child Abuse and Neglect 101(January):104356. doi: 10.1016/j.chiabu.2020.104356.

[3] Gokcekus, Omer, and Tufan Ekici. 2020. "Religion, Religiosity, and Corruption." Review of Religious Research 62(4):563-81. doi: 10.1007/s13644-020-00421-2.

[4] Jackson, Matthew O., and Yiqing Xing. 2018. "The Interaction of Communities, Religion, Governments, and Corruption in the Enforcement of Contracts and Social Norms.” SSRN Electronic Journal 2018(September). doi: 10.2139/ssrn.3153842.

[5] Jajkowicz, Ondřej, and Agata Drobiszová. 2015. "The Effect of Corruption on Government Expenditure Allocation in OECD Countries." Acta Universitatis Agriculturae et Silviculturae Mendelianae Brunensis 63(4):1251-59. doi: 10.11118/actaun201563041251.

[6] Kholid, Anwar, Rahmawati Husein, Dyah Mutiarin, and Septiyan Listiya E. R. 2015. "The Influence of Social Media Towards Student Political Participation During the 2014 Indonesian Presidential Election.” Journal of Government and Politics 6(2). doi: 10.18196/jgp.2015.0019.

[7] Li, Chunkai, Qiaobing Wu, and Zurong Liang. 2019. "Effect of Poverty on Mental Health of Children in Rural China: The Mediating Role of Social Capital." Applied Research in Quality of Life 14(1):131-53. doi: 10.1007/s11482-017-9584-x.

[8] Makmur, Kartini Laras. 2020. "Can Religion Prevents Corruption? The Indonesian Exprience.” Al Wasath Jurnal Ilmu Hukum 1(1):13-24.

[9] Miklian, Jason, and Ida Roland Birkvad. 2016. "Religion, Poverty and Conflict in a Garbage Slum of Ahmedabad.” International Area Studies Review 19(1):60-75. doi: $10.1177 / 2233865916631925$.

[10] Mukhammadsidiqov, Mukhammadolim. 2020. "The Light of Islam The Importance of Regulating the Relationship between the State and Religion in Ensuring the Stability of Society." 2020(2). 
[11] Nakagawa, Toru. 2018. "TRIZ/CrePS Approach to the Social Problems of Poverty: 'Liberty vs. Love' Is Found the Principal Contradiction of the Human Culture." Advances and Impacts of the Theory of Inventive Problem Solving 179-88. doi: 10.1007/978-3-319-96532-1_17.

[12] Ngwoke, Peace Ngozi. 2020. "The Place of Religion in Combating Corruption in Nigeria.” Journal of Church and State 0(0):1-21. doi: 10.1093/jcs/csaa058.

[13] Orok, Emmanuel, Duke Justus, and Onyebuchi Okafor. 2020. "Poverty Alleviation Policies of Selected Churches in Anambra State , Nigeria." 3(1):40-52.

[14] Rahmat, Al Fauzi, and Eko Priyo Purnomo. 2020. "Twitter Media Platform to Set-Up Political Branding: Analyzing @Kiyai_Marufamin in 2019 Presidential Election Campaign." Nyima: Journal of Communication 4(1):73. doi: 10.31000/nyimak.v4i1.2268.

[15] Riaz, Qasim, Muhammad Farrukh, Shams-Ur Rehman, and Amir Ishaque. 2016. "Religion and Entrepreneurial Intentions: An Empirical Investigation." International Journal of ADVANCED AND APPLIED SCIENCES 3(9):31-36. doi: 10.21833/ijaas.2016.09.006.

[16] Saar-Heiman, Yuval, Maya Lavie-Ajayi, and Michal Krumer-Nevo. 2017. "PovertyAware Social Work Practice: Service Users' Perspectives.” Child and Family Social Work 22(2):1054-63. doi: 10.1111/cfs.12325.

[17] Setiawan, Deni, and Achmad Nurmandi. 2020. "Sandiaga Uno : Personal Branding Di Twitter.” Jurnal Public Policy 6(1):19. doi: 10.35308/jpp.v6i1.1657.

[18] University of Stellenbosch. Department of Biblical Studies., Obaji M., and Ignatius Swart. 2015. "Scriptura : Tydskrif Vir Bybelkunde." Scriptura 114(85113):1-20.

[19] WIDIYANTO, IWAN FIRMAN WIDIYANTO. 2017. "'Religion and Corruption."” JURNAL ABDIEL (April):13-30.

[20] Yagboyaju, Dhikru A. 2017. "Religion, Culture and Political Corruption in Nigeria." Africa's Public Service Delivery and Performance Review 5(1):10. doi: 10.4102/apsdpr.v5i1.151.

[21] Yahya, Khulida Kirana, Tan Fee Yean, Johanim Johari, and Nur Ain Saad. 2006. "Corruption Censure among Gen Y Public Servants: Do Organizational Culture, Work Values and Religiosity Matter?” International Business Management 10(16):3567-74.

[22] Zakaria, Patty. 2018. "Religiosity and Corruption." Corruption and Norms 69-90. doi: 10.1007/978-3-319-66254-1_5.

[23] Zarkadakis, George. 2020. "Foreword: Toward a New Social Contract for the Digital Economy.” Cyber Republic (January). doi: 10.7551/mitpress/11853.003.0001. 